
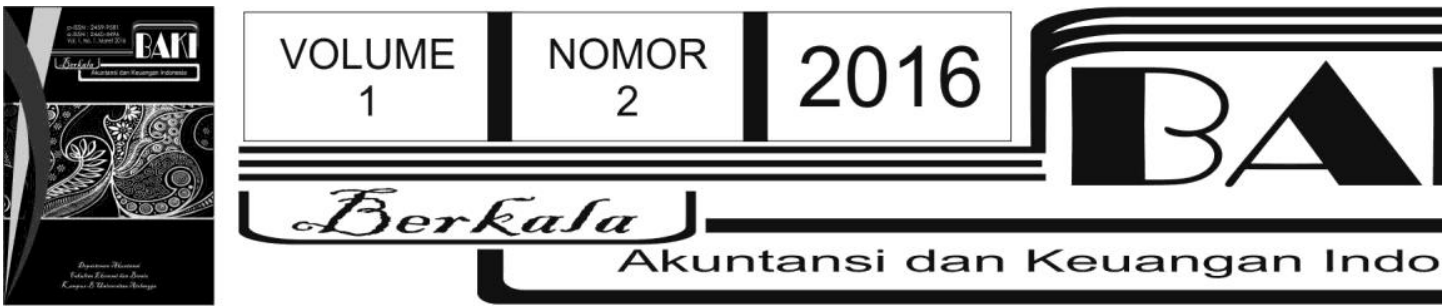

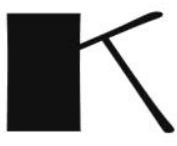

\title{
Berkata
}

Akuntansi dan Keuangan Indonesia

\section{Dampak Faktor-Faktor Demografi Terhadap Kepatuhan Perpajakan di Indonesia}

\section{Ganda Frisno Pasaribu*, Christine Tjen}

\author{
*Universitas Indonesia \\ *gandafrisno@gmail.com
}

\begin{tabular}{|c|c|}
\hline INFO ARTIKEL & ABSTRAK \\
\hline $\begin{array}{l}\text { Histori Artikel: } \\
\text { Tanggal Masuk } 2 \text { Agustus } 2016 \\
\text { Tanggal Diterima } 14 \text { September } \\
2016 \\
\text { Tersedia Online } 30 \text { September } \\
2016 \\
\text { Kata Kunci: } \\
\text { pajak; } \\
\text { kepatuhan perpajakan; } \\
\text { faktor demografi }\end{array}$ & $\begin{array}{l}\text { Penelitian ini bertujuan untuk mengetahui bagaimana dampak } \\
\text { faktor-faktor demografi terhadap perilaku Kepatuhan Perpajakan. } \\
\text { Perilaku kepatuhan perpajakan dilihat dari intensi Wajib Pajak } \\
\text { untuk melakukan tax evasion. Pengumpulan data dilakukan } \\
\text { dengan cara menyebarkan kuesioner dan jumlah sampel } \\
\text { sebanyak } 304 \text { responden. Hasil penelitian ini menunjukkan bahwa } \\
\text { responden laki-laki dan perempuan mempunyai kepatuhan } \\
\text { perpajakan yang sama. Hasil penelitian juga menunjukkan bahwa } \\
\text { tidak ada perbedaan kepatuhan perpajakan antara responden } \\
\text { yang sudah menikah dengan yang belum menikah. Variabel } \\
\text { independen tingkat pendidikan, jenis pekerjaan dan tingkat } \\
\text { penghasilan berkorelasi secara signifikan terhadap kepatuhan } \\
\text { perpajakan }(p<0,05) \text {. }\end{array}$ \\
\hline
\end{tabular}

\section{Pendahuluan}

Ketidakpatuhan perpajakan merupakan masalah yang dihadapi oleh semua otoritas pajak. Masalah ketidakpatuhan perpajakan bisa dikatakan sudah ada sejak pajak pertama kali diterapkan. Penjelasan dan pengelompokan pola dan perilaku ketidakpatuhan perpajakan Wajib Pajak dan menemukan cara yang paling tepat untuk mengurangi tingkat ketidakpatuhan menjadi hal paling penting bagi otoritas perpajakan (Andreoni et al., 1998).

Bisa dipahami jika Wajib Pajak tidak secara sukarela membayar pajak sehingga mereka melakukan berbagai tindakan untuk mengurangi beban pajak mereka (Alm dan Torgler 2011). Secara umum, kepatuhan perpajakan berarti pelaporan dasar pengenaan pajak (penghasilan) yang sebenarnya, perhitungan pajak terutang dengan benar, penyampaian Surat Pemberitahuan (SPT) tepat waktu, dan pembayaran pajak yang masih harus dibayar secara tepat waktu. Sebagian besar tindakan penggelapan pajak adalah sengaja melaporkan dasar pengenaan pajak (penghasilan) yang tidak benar. Tindakan ini menyebabkan perbedaan 
perhitungan dan penyetoran pajak yang dilakukan oleh Wajib Pajak dengan pajak yang seharusnya terutang, yang dikenal sebagai tax gap.

Literatur perpajakan mengidentifikasi faktor-faktor, baik ekonomi dan nonekonomi, penentu keputusan ketidakpatuhan Wajib Pajak. Sikap dan perilaku Wajib Pajak dipengaruhi oleh banyak faktor, salah satunya adalah faktor demografi. Hasil penelitian menyimpulkan bahwa berbagai faktor demografi berkorelasi dengan perilaku kepatuhan perpajakan, seperti usia, jenis kelamin, tingkat pendidikan, tingkat penghasilan, status perkawinan dan jenis pekerjaan. Meskipun alasan yang tepat untuk korelasi belum diketahui, namun pengetahuan tentang hubungan korelasi faktor demografi dengan perilaku kepatuhan perpajakan berguna dalam penyusunan strategi peningkatan kepatuhan Wajib Pajak.

Berdasarkan hasil penjelasan di atas, peneliti memperoleh informasi mengenai variabel yang relevan memengaruhi kepatuhan perpajakan. Hal ini juga relevan untuk menentukan apakah kesimpulan dari penelitian ini memperkuat atau menyangkal penelitian kepatuhan perpajakan sebelumnya yang dilakukan di negara lain. Dengan kata lain, apakah Wajib Pajak Indonesia adalah individu yang unik atau apakah perilaku mereka mengikuti pola yang telah diidentifikasi pada penelitian kepatuhan perpajakan di negara lain? Hasil penelitian ini juga akan membantu otoritas perpajakan Indonesia dalam penyusunan strategi peningkatan kepatuhan Wajib Pajak dengan penitikberatan pada profil demografi Wajib Pajak.

\section{Tinjauan Pustaka}

Kepatuhan perpajakan dapat didefinisikan sebagai suatu keadaan dimana wajib pajak memenuhi semua kewajiban perpajakan dan melaksanakan hak perpajakannya (Nurmantu 2005). Menurut James dan Alley (2002), kepatuhan perpajakan mengacu pada kesediaan individu untuk bertindak sesuai dengan hukum dan peraturan pajak tanpa didahului penegakan hukum. Organisation for Economic Co-operation and Development (OECD) dalam mendefinisikan kepatuhan perpajakan membagi kepatuhan perpajakan mejadi dua kategori (OECD 2008), yaitu:

a. Kepatuhan administratif, yakni kepatuhan terhadap peraturan administratif yang diukur dengan kepatuhan dalam menyampaikan laporan dan membayar pajak. Kepatuhan administratif ini dikenal dengan kepatuhan formal.

b. Kepatuhan teknis, yakni kepatuhan yang mengacu pada perhitungan jumlah beban pajak secara benar. Kepatuhan teknis ini dikenal dengan kepatuan material.

Secara tidak langsung, OECD mendefinisikan kepatuhan pajak sebagai suatu keadaan dimana Wajib Pajak memenuhi semua kewajiban perpajakan dan melaksanakan hak perpajakannya baik dalam bentuk formal maupun material. 
Dengan demikian, kepatuhan perpajakan mengacu pada kesediaan, kemauan, dan kemampuan Wajib Pajak untuk tunduk dan patuh terhadap peraturan perundang-undangan perpajakan yang berlaku, melaporkan penghasilan, dan membayar pajak dengan benar dan tepat waktu. Pemenuhan peraturan perundang-undangan perpajakan tersebut haruslah dilakukan secara suka rela oleh Wajib Pajak tanpa didahului pemeriksaan, investigasi, peringatan, ancaman, dan penerapan sanksi baik pidana maupun administrasi.

Kepatuhan Wajib Pajak juga meliputi ketidakpatuhan yaitu ketidakpatuhan yang disengaja dan ketidakpatuhan yang tidak disengaja. Ketidakpatuhan yang tidak disengaja terjadi karena Wajib Pajak tidak mengetahui atau memahami aturan pajak sehingga mengalami kesulitan dalam pelaksanaan kewajiban perpajakannya. Ketidakpatuhan yang disengaja merupakan pelanggaran terhadap peraturan perpajakan karena wajib pajak berusaha menghindari kewajiban perpajakannya.

Adapun bentuk-bentuk ketidakpatuhan perpajakan menurut Plumley (2005) adalah sebagai berikut:

a. Ketidakpatuhan dalam menyampaikan SPT (tidak tepat waktu menyampaikan SPT atau tidak menyampaikan SPT sama sekali),

b. Ketidakpatuhan dalam pelaporan penghasilan (tidak melaporkan semua penghasilan yang diterima selama setahun), dan

c. Ketidakpatuhan dalam pembayaran pajak (tidak membayar pajak yang terutang secara tepat waktu atau kurang membayar pajak terutang).

Dari penjelasan di atas dapat dilihat bahwa status Wajib Pajak patuh tidak diukur dari besarnya pajak yang dibayar (kontribusi pajak) namun diukur dari pemenuhan kewajiban perpajakan sesuai dengan ketentuan peraturan perundangan perpajakan yang berlaku. Dengan kata lain, objek pengukuran dalam kepatuhan perpajakan adalah perilaku Wajib Pajak.

\section{Pengembangan Hipotesis}

Pajak adalah tambahan beban bagi Wajib Pajak. Sebagai manusia yang rasional, Wajib Pajak akan melakukan berbagai cara untuk menghemat beban-beban yang tidak memberikan manfaat langsung. Motivasi inilah yang memengaruhi perilaku kepatuhan perpajakan Wajib Pajak.

Berdasarkan review yang dilakukan oleh Jackson dan Milliron (1986) atas hasil penelitian di bidang kepatuhan perpajakan dari tahun 1974 sampai dengan 1985, disimpulkan ada 14 variabel yang memengaruhi perilaku kepatuhan perpajakan, yakni umur, jenis kelamin, pendidikan, tingkat penghasilan, sumber penghasilan, jenis pekerjaan, pengaruh pasangan/keluarga, etika, keadilan, kompleksitas, hubungan dengan otoritas pajak, sanksi, 
kemungkinan diaudit, dan tarif pajak. Dari empat belas variabel tersebut terlihat bahwa faktor demografi merupakan faktor penentu dalam pembentukan perilaku kepatuhan perpajakan.

Variabel jenis kelamin digunakan dalam penelitian perpajakan. Studi-studi yang telah dilakukan menunjukkan hasil yang tidak konsisten. Meskipun belum banyak dukungan riset, terdapat kecenderungan bahwa perempuan lebih jujur dan patuh dibandingkan laki-laki. Penelitian terdahulu mengenai kepatuhan pajak juga menemukan bahwa laki-laki kurang patuh terhadap peraturan perpajakan jika dibandingkan dengan perempuan (Tittle 1980). Torgler dan Schaltegger (2005) menemukan bahwa perempuan mempunyai tingkat kepatuhan pajak yang lebih tinggi daripada laki-laki. McGee dan Smith (2007) menemukan bahwa wanita lebih menentang tax evasion dibandingkan laki-laki. Di sisi lain, hasil penelitian Roxas dan Stoneback (2004) menyimpulkan bahwa antara perempuan dan laki-laki tidak ada perbedaan dalam hal kepatuhan perpajakan. Hasil yang sama juga disimpulkan oleh Al-Mamun et al. (2014) bahwa tidak ada perbedaan signifikan dalam hal kepatuhan perpajakan antara laki-laki dan perempuan. Berdasarkan penjelasan konsep dan hasil-hasil penelitian empiris di atas dirumuskan hipotesis pertama sebagai berikut:

\section{$H_{1}$ : Jenis Kelamin Wajib Pajak berhubungan dengan kepatuhan perpajakan.}

Modal sosial (social capital) individu semakin bertambah seiring dengan bertambahnya usia. Semakin dewasa, seseorang akan semakin terikat dalam suatu komunitas. Perilaku individu dewasa juga semakin terikat dengan perilaku dalam komunitas. Efek positif dari hal ini adalah individu dewasa akan menghindari tindakan-tindakan yang bisa menimbulkan sanksi sosial seperti sanksi sosial karena melakukan penggelapan pajak. Torgler dan Schaltegger (2005) menemukan bahwa orang yang lebih tua lebih sensitif terhadap ancaman sanksi perpajakan. Hasil penelitian mereka menunjukkan bahwa umur berpengaruh signifikan dan positif terhadap tax compliance.

Namun hasil berbeda diperoleh McGee dan Smith (2007). Mereka menguji hubungan antara umur terhadap perilaku penggelapan pajak dan menemukan bahwa tidak ada perbedaan perilaku yang signifikan antara responden yang berumur di bawah 25 tahun dan 25 tahun ke atas.

Torgler dan Valev (2004) juga menemukan bahwa umur berkorelasi negatif dengan pelanggaran aturan. Hasil yang sama ditemukan oleh Al-Mamun et al. (2014). Pada penelitiannya, mereka menyimpulkan bahwa umur berkorelasi negatif terhadap kepatuhan perpajakan, artinya orang yang lebih muda lebih patuh dibandingkan dengan orang yang lebih tua. Dari penjelasan konsep dan hasil-hasil penelitian empiris di atas rumusan hipotesis kedua adalah sebagai berikut: 


\section{$\mathrm{H}_{2}$ : Umur Wajib Pajak berhubungan dengan kepatuhan perpajakan.}

Semakin tinggi tingkat pendidikannya maka seseorang akan lebih mengetahui perpajakan dan memahami manfaat membayar pajak jika dibandingkan dengan individu yang berpendidikan lebih rendah. Hal ini akan mendorong orang yang berpendidikan lebih tinggi akan lebih patuh. Sebaliknya, tingkat pendidikan yang tinggi menunjukkan tingkat etika dan moral pajak yang tinggi pula (Song dan Yarbrough 1978; Torgler dan Schaltegger 2005; AlMamun et al., 2014).

Namun menurut Lewis (1982) orang yang mempunyai pendidikan yang lebih tinggi akan lebih mengetahui tentang peraturan pajak dan kebijakan fiskal serta mengetahui tentang caracara menghindari pajak (tax avoidance) dan penyelundupan pajak (tax evasion) sehingga tidak dapat dikatakan bahwa orang yang berpendidikan tinggi lebih patuh dari yang berpendidikan rendah. Berdasarkan argumen yang saling berlawanan tersebut, penelitian ini akan menguji hubungan antara tingkat pendidikan dengan tingkat kepatuhan pajak dengan hipotesis ketiga sebagai berikut:

\section{$H_{3}$ : Tingkat pendidikan Wajib Pajak berhubungan dengan kepatuhan perpajakan.}

Hasil penelitian terkait hubungan status perkawinan terhadap Kepatuhan Perpajakan ternyata berbeda. Torgler (2003) menemukan bahwa individu yang lajang memiliki kepatuhan perpajakan lebih rendah dibandingkan dengan pasangan yang sudah menikah. Orang yang sudah menikah lebih terikat pada komunitas sehingga mereka akan menghindari tindakantindakan yang dapat menimbulkan sanksi sosial seperti melakukan penggelapan pajak. Namun, Andreoni et al. (1998) menemukan bahwa tingkat kepatuhan pasangan yang sudah menikah lebih rendah dari pada individu yang masih lajang. Pendapat ini didukung hipotesis bahwa pengeluaran orang yang sudah menikah cenderung meningkat. Hal ini mendorong orang yang menikah cenderung melakukan penghematan termasuk melakukan penggelapan pajak. Berdasarkan argumen yang saling berlawanan tersebut, penelitian ini akan menguji hubungan antara status pernikahan dengan tingkat kepatuhan pajak di Indonesia dengan hipotesis keempat sebagai berikut:

\section{$H_{4}$ : Status Pernikahan Wajib Pajak berhubungan dengan kepatuhan perpajakan.}

Perbedaan mekanisme pemungutan pajak atas penghasilan yang diterima oleh karyawan dengan wiraswasta dapat memengaruhi kepatuhan perpajakan Wajib Pajak. Pelaporan pihak ketiga atas pemotongan pajak juga akan mendorong kepatuhan perpajakan. Bagi karyawan, 
penghasilan yang diterimanya telah dipotong pajak oleh pemberi kerja. Jika seorang karyawan hanya bekerja di satu pemberi kerja bisa dikatakan bahwa dia patuh dalam hal pembayaran pajak karena pajak terutang atas penghasilannya sama dengan besarnya pemotongan pajak yang dilakukan pemberi kerja. Hal berbeda terjadi bagi wiraswasta dimana banyak penghasilan mereka tidak dipotong pajak oleh pemberi penghasilan. Literatur kepatuhan pajak menyimpulkan bahwa wajib pajak wiraswasta lebih mudah menghindari pajak dibanding karyawan. Wiraswasta memiliki biaya kepatuhan pajak yang tinggi sehingga mereka cenderung menggelapkan pajak (Lewis 1982). Wiraswasta juga memiliki lebih banyak kesempatan untuk menghindari pajak daripada wajib pajak yang atas penghasilannya telah dipotong pajak oleh pemberi kerja. Berdasarkan penjelasan konsep dan hasil-hasil penelitian empiris di atas dirumuskan hipotesis kelima sebagai berikut:

\section{H5: Jenis Pekerjaan Wajib Pajak berhubungan dengan kepatuhan perpajakan.}

Sulit untuk menilai secara teoritis hubungan antara tingkat penghasilan dengan tingkat kepatuhan pajak (Torgler dan Schneider 2004). Keputusan individu untuk patuh dengan tingkat penghasilan tertentu didasarkan pada preferensi risiko dan tarif progresif yang berlaku. Tarif pajak progresif mendorong individu berpenghasilan besar untuk melakukan penggelapan pajak. Sedangkan individu berpenghasilan rendah kurang berani untuk mengambil risiko penggelapan pajak karena hal ini akan berakibat penurunan kekayaan jika pelanggaran pajak terdeteksi fiskus.

Beberapa penelitian, baik eksperimental maupun tinjauan arsip, menghasilkan beragam kesimpulan mengenai hubungan antara tingkat pendapatan dan kepatuhan perpajakan. Sebagai contoh, Alm et al. (1992) menemukan bahwa jumlah penghasilan yang dilaporkan pada SPT Tahunan meningkat dengan meningkatnya pendapatan yang diterima Wajib Pajak. Menurut penelitian mereka, terdapat hubungan positif antara pendapatan dan kepatuhan. Beberapa penelitian eksperimental lainnya melaporkan hubungan negatif antara pendapatan dan kepatuhan perpajakan (Trivedi dan Chung 2006). Berdasarkan uraian tersebut, penelitian ini akan menguji hubungan antara tingkat penghasilan dengan tingkat kepatuhan pajak dengan hipotesis keenam sebagai berikut:

$H_{6}$ : Tingkat penghasilan Wajib Pajak berhubungan dengan kepatuhan perpajakan. 


\section{Metode Penelitian}

Variabel penelitian ini terdiri dari dua variabel, yaitu variabel terikat dan variabel bebas. Variabel terikat pada penelitian ini adalah Kepatuhan Perpajakan, sedangkan variabel bebas Faktor Demografi, yakni Umur, Jenis Kelamin, Jenis Pekerjaan, Tingkat Pendidikan, Status Perkawinan, dan Tingkat Penghasilan.

\section{Tabel1}

\section{Definisi Operasional Variabel}

\begin{tabular}{|l|l|l|}
\hline \multicolumn{1}{|c|}{ Nama Variabel } & \multicolumn{1}{|c|}{ Definisi } & Pengukuran \\
\hline $\begin{array}{l}\text { Kepatuhan } \\
\text { Perpajakan }\end{array}$ & $\begin{array}{l}\text { pemenuhan peraturan perpajakan serta pelaporan } \\
\text { penghasilan secara akurat dan jujur }\end{array}$ & $\begin{array}{l}\text { Skala likert 6 } \\
\text { point }\end{array}$ \\
\hline Umur & Umur responden & Kategori \\
\hline Jenis kelamin & Jenis Kelamin Responden & $\begin{array}{l}\text { Angka numerik } \\
\text { (dummy: } 0,1)\end{array}$ \\
\hline $\begin{array}{l}\text { Tingkat } \\
\text { Penghasilan }\end{array}$ & Jumlah penghasilan yang diterima dalam setahun & Kategori \\
\hline Jenis pekerjaan & Jenis pekerjaan & Kategori \\
\hline $\begin{array}{l}\text { Tingkat } \\
\text { pendidikan }\end{array}$ & Tingkat pendidikan tertinggi yang telah dicapai & Kategori \\
\hline Status perkawinan & Status perkawinan responden & $\begin{array}{l}\text { Angka numerik } \\
\text { (dummy: } 0,1)\end{array}$ \\
\hline
\end{tabular}

Populasi penelitian ini adalah Wajib Pajak Orang Pribadi. Teknik pengambilan sampel yang digunakan dalam penelitian ini adalah teknik pengambilan sampel probalistik (random sampling), yaitu pengambilan sampel yang dilakukan secara acak. Pengambilan sampel yang digunakan adalah teknik convenience, dengan melakukan penyebaran kuesioner melalui sarana yang ada, namun yang dijadikan sampel adalah kuesioner yang telah diisi dengan lengkap yang diterima kembali peneliti.

Data yang digunakan pada penelitian ini adalah data primer. Data primer diperoleh dengan menyebarkan kuesioner kepada responden. Kuesioner disebarkan secara online melalui Google Docs dengan harapan responden akan lebih jujur dalam mengisi kuesioner karena responden memiliki privasi dalam pengisiannya.

Kuesioner ini diberikan untuk mengetahui kondisi demografi dan kepatuhan pajak responden. Kuesioner dalam penelitian ini merupakan hasil pengembangan dari kuesioner penelitian sebelumnya yaitu penelitian Al-Mamun et al. (2014). Penyesuaian yang dilakukan adalah pada faktor demografi yang menjadi variabel bebas penelitian. Pada penelitiannya, AlMamun et al. (2014) menggunakan faktor demografi berupa umur, jenis kelamin, etnik, tingkat pendidikan dan penghasilan sebagai variabel bebas. Pada penelitian ini variabel etnik tidak dimasukan, namun peneliti menambahkan variabel status perkawinan pada faktor demografi. 
Berbeda dengan Malaysia yang terdiri dari tiga etnik, yakni Melayu, Cina, dan India, Indonesia memiliki banyak etnik yang dapat dilihat dengan banyaknya suku yang ada di Indonesia. Hal ini menjadi alasan mengapa peneliti tidak memasukkan variabel etnik sebagai variabel independen. Peneliti menambahkan variabel status perkawinan karena berdasarkan penelitian Andreoni et al. (1998) disimpulkan bahwa status perkawinan memengaruhi kepatuhan perpajakan. Mereka berpendapat bahwa biaya hidup yang ditanggung oleh orang yang sudah menikah umumnya akan lebih besar dari yang belum menikah. Oleh karena pajak yang terutang merupakan pengurang penghasilan yang diterima seseorang sehingga memengaruhi kemampuan ekonomis orang tersebut dan keinginan Wajib Pajak yang sudah menikah untuk membayar pajak.

Kuesioner pada penelitian ini terbagi menjadi dua bagian. Bagian pertama berisi pertanyaan mengenai demografi responden dan bagian kedua mengenai pernyataan tax evasion. Poin yang ditanyakan pada bagian pertama adalah faktor demografi responden yang menjadi variabel bebas, yakni Jenis Kelamin, Umur Tingkat Pendidikan, Latar Belakang Pendidikan, Status Pernikahan, Jenis Pekerjaan, dan Total Penghasilan selama setahun. Responden juga diminta untuk mengisi kuesioner Sikap Kepatuhan Perpajakan untuk mengetahui gambaran kepatuhan perpajakan responden. Kuesioner ini terdiri atas 13 (tiga belas) butir pernyataan tax evasion. Skala yang digunakan dalam ketiga belas butir pernyataaan ini adalah Skala Likert dengan 6 poin, di mana semakin besar nilai yang dipilih oleh responden maka responden akan dikatakan Wajib Pajak patuh.

\section{Analisis dan Pembahasan}

\subsection{Uji Validitas dan Uji Reliabilitas Kuesioner}

Sebelum melakukan pengumpulan data, peneliti terlebih dahulu melakukan uji validitas dan reliabilitas kuesioner. Uji validitas yang digunakan adalah construct validity (validitas konstruk). Cara mengukur validitas konstruk adalah mengorelasikan jumlah skor item dengan jumlah skor total. Tiap butir pertanyaan/pernyataan dalam sebuah alat ukur dinyatakan valid jika nilai correlated item lebih besar dari 0,2.

Tabel 2. Hasil Uji Validitas Variabel Kepatuhan Perpajakan

\begin{tabular}{|c|c|c|}
\hline Butir & Correlated Item & Keterangan \\
\hline PATUH1 & 0,482 & Valid \\
PATUH2 & 0,556 & Valid \\
PATUH3 & 0,619 & Valid \\
PATUH4 & 0,386 & Valid \\
PATUH5 & 0,427 & Valid
\end{tabular}




\begin{tabular}{|c|c|c|}
\hline Butir & Correlated Item & Keterangan \\
\hline PATUH6 & 0,365 & Valid \\
PATUH7 & 0,624 & Valid \\
PATUH8 & 0,759 & Valid \\
PATUH9 & 0,559 & Valid \\
PATUH10 & 0,619 & Valid \\
PATUH11 & 0,688 & Valid \\
PATUH12 & 0,759 & Valid \\
PATUH13 & 0,571 & Valid \\
\hline
\end{tabular}

Uji reliabilitas yang digunakan adalah Cronbach Alpha. Cronbach Alpha merupakan koefisien reliabilitas yang mengindikasikan seberapa baik item-item yang ada dalam suatu alat ukur berkorelasi positif dengan yang lainnya. Suatu alat ukur dikatakan reliabel jika nilai Cronbach Alpha> 0,6. Hasil uji reliabilitas diperoleh nilai koefisien Cronbach Alpha lebih besar dari 0,6 sehingga alat ukur yang digunakan adalah reliabel.

\subsection{Gambaran Umum Responden}

Peneliti menyebarkan kuisioner secara online dengan menggunakan Google Docs. Proses pengumpulan data dilakukan selama satu setengah bulan mulai dari awal November 2014 s.d. pertengahan Desember 2014. Sampai dengan batas waktu yang ditetapkan oleh peneliti, jumlah responden yang telah melakukan pengisian kuesioner berjumlah 304 responden. Sehingga sampel yang digunakan dalam penelitian ini berjumlah 304 .

Tabel 2 mengambarkan ringkasan data faktor demografi responden. Data faktor demografi ini sekaligus menjadi variabel bebas dari penelitian ini. Faktor demografi yang dimaksud adalah Umur, Jenis Kelamin, Jenis Pekerjaan, Tingkat Pendidikan, Status Perkawinan, dan Tingkat Penghasilan.

Tabel 3. Gambaran Umum Responden

\begin{tabular}{|l|l|r|r|}
\hline \multicolumn{2}{|c|}{ Karakteristik } & $\begin{array}{r}\text { Jumlah } \\
(\mathrm{N}=304)\end{array}$ & (\%) \\
\hline \multirow{4}{*}{ Umur } & Di bawah 35 tahun & 189 & 62 \\
\cline { 2 - 4 } & 36 tahun s.d 45 tahun & 63 & 21 \\
\cline { 2 - 4 } & 45 tahun s.d 55 tahun & 31 & 10 \\
\cline { 2 - 4 } & Di atas 55 tahun & 21 & 7 \\
\hline \multirow{3}{*}{ Jenis Kelamin } & Laki-laki & 163 & 54 \\
\cline { 2 - 4 } & Perempuan & 141 & 46 \\
\hline \multirow{5}{*}{ Tingkat Pendidikan } & SMA & 7 & 2 \\
\cline { 2 - 4 } & D3 & 60 & 20 \\
\cline { 2 - 4 } & D IV/S1 & 128 & 42 \\
\cline { 2 - 4 } & S2 & 95 & 31 \\
\hline
\end{tabular}




\begin{tabular}{|l|l|r|r|}
\hline \multicolumn{2}{|c|}{ Karakteristik } & $\begin{array}{r}\text { Jumlah } \\
(\mathrm{N}=304)\end{array}$ & (\%) \\
\hline & S3 & 14 & 5 \\
\hline \multirow{4}{*}{ Status Pernikahan } & Belum Menikah & 149 & 49 \\
\cline { 2 - 4 } & Menikah & 155 & 51 \\
\hline \multirow{5}{*}{ Tingkat Penis Pekerjaan } & Pegawai Negeri Sipil & 93 & 31 \\
\cline { 2 - 4 } & Karyawan Swasta/BUMN & 130 & 43 \\
\cline { 2 - 4 } & Profesional & 51 & 17 \\
\cline { 2 - 4 } & Pengusaha & 30 & 10 \\
\hline & Sampai dengan 50 juta & 40 & 13 \\
\cline { 2 - 4 } & 50 juta s.d 250 juta & 170 & 56 \\
\cline { 2 - 4 } & 250 juta s.d 500 juta & 45 & 15 \\
\cline { 2 - 4 } & Di atas 500 juta & 49 & 16 \\
\hline
\end{tabular}

Pada penelitian ini, umur responden dikelompokkan menjadi empat kelompok. Dari keempat kelompok ini, kelompok I merupakan kelompok dengan jumlah responden terbanyak, yakni sebesar $62 \%(n=189)$ dari seluruh responden. Persentase responden dengan kelompok umur antara 35 tahun s.d 45 tahun mencapai $21 \%(n=63)$, persentase responden dengan kelompok umur antara 45 tahun s.d 55 tahun mencapai 10\% $(n=31)$. Sedangkan persentase responden dengan umur di atas 55 tahun mencapai $7 \%(n=21)$.

Dari 304 responden yang melakukan pengisian kuesioner, persentase responden laki-laki adalah 54\% $(n=163)$ dan responden perempuan sebanyak $46 \%(n=141)$. Terlihat jika sebagian besar responden penelitian ini adalah laki-laki. Persentase responden yang belum menikah adalah $49 \%(n=149)$, sedangkan persentase responden yang sudah menikah adalah $51 \%$ $(n=155)$.

Mayoritas responden sudah mencapai tingkat pendidikan terakhir DIV/S1 yakni sebanyak $42 \%(n=128)$. Responden dengan tingkat pendidikan terakhir SMA mencapai $2 \%(n=7)$. Responden dengan tingkat pendidikan terakhir DIII mencapai 20\% $(n=60)$, responden dengan tingkat pendidikan S2 mencapai 31\% ( $n=95)$, sedangkan responden dengan tingkat pendidikan S3 mencapai 5\% $(n=14)$.

Persentase responden yang bekerja sebagai Pegawai Negeri Sipil mencapai 30\% ( $n=93)$, kemudian persentase responden yang bekerja sebagai Karyawan Swasta/BUMN mencapai $43 \%(n=130)$, dan persentase responden yang bekerja sebagai Profesional adalah $17 \%(n=51)$, serta persentase responden yang menjadi Pengusaha adalah $10 \%(n=30)$.

Pada penelitian ini, tingkat penghasilan responden dikelompokkan sesuai dengan lapisan penghasilan kena pajak Wajib Pajak orang pribadi pada Pasal 17 UU Pajak Penghasilan. Dari 304 responden, persentase responden berpenghasilan sampai dengan $\mathrm{Rp} 50$ juta/tahun adalah $13 \%(n=40)$, persentase responden berpenghasilan Rp 50 juta s.d Rp 250 juta/tahun adalah $56 \%(n=170)$, persentase responden berpenghasilan Rp 250 juta s.d Rp 500 juta/tahun 
mencapai 15\% $(n=45)$ dan persentase responden berpenghasilan di atas $R p 500$ juta/tahun adalah $16 \%(n=49)$.

\subsection{Hasil Analisis Utama}

Pada subbab ini, peneliti akan menjelaskan temuan hasil pengolahan statistik terkait variabel penelitian, yaitu variabel faktor demografi dan variabel kepatuhan perpajakan. Oleh karena data variabel penelitian ini melibatkan data berjenis nominal dan ordinal maka peneliti menggunakan uji statistik nonparametrik. Pada penelitian ini, uji statistik nonparametrik yang digunakan adalah Uji Kruskal-Wallis dan uji korelasi Spearman.

Tabel 4. Hasil Uji Kruskal-Walis dan Uji Korelasi Spearman

\begin{tabular}{|c|c|c|c|c|}
\hline \multirow[b]{2}{*}{ Variabel } & \multicolumn{2}{|c|}{ Uji Kruskal-Wallis } & \multicolumn{2}{|c|}{ Uji Korelasi Spearman } \\
\hline & Chi2 & $\begin{array}{l}\text { Asymp. } \\
\text { Sig }\end{array}$ & Coef. & Sig. \\
\hline Jenis Kelamin & 0,101 & 0,751 & $-0,018$ & 0,751 \\
\hline Umur & 5,968 & 0,113 & $-0,137^{\star}$ & 0,017 \\
\hline Tingkat Pendidikan & 11,579 & 0,021 & $-0,168^{* *}$ & 0,003 \\
\hline Status Pernikahan & 0,740 & 0,390 & $-0,049$ & 0,391 \\
\hline Jenis Pekerjaan & 18,508 & 0,000 & $-0,220^{* *}$ & 0,000 \\
\hline Tingkat Penghasilan & 11,735 & 0,008 & $-0,192^{* *}$ & 0,001 \\
\hline
\end{tabular}

\subsubsection{Hubungan Jenis Kelamin Terhadap Kepatuhan Perpajakan}

Tidak ada perbedaan kepatuhan perpajakan antara responden berjenis kelamin laki-laki maupun responden berjenis kelamin perempuan yang ditunjukkan dengan nilai $p$-value (Asymp. Sig) bernilai 0,751 lebih besar dari 0,05 sehingga dapat dinyatakan $\mathrm{H}_{1}$ ditolak. Hasil uji korelasi menunjukkan bahwa Jenis Kelamin berpengaruh tidak signifikan $(p>0,05)$ dan memiliki hubungan dengan arah negatif terhadap kepatuhan perpajakan dengan kekuatan hubungan sangat lemah $(r=-0,018)$. Hasil ini selaras dengan penelitian yang dilakukan oleh Roxas dan Stoneback (2004) dan Al-Mamun et al. (2014). Mereka menemukan bahwa tidak ada perbedaan kepatuhan perpajakan antara laki-laki dan perempuan. Mereka menyimpulkan bahwa hal ini disebabkan karena ada persamaan persepsi antara laki-laki dan perempuan atas kewajiban perpajakan dan manfaat dari pajak. Meskipun hasil penelitian ini berbeda dengan hasil penelitian Tittle (1980), Torgler dan Schaltegger (2005), dan McGee dan Smith (2007) dimana menemukan bahwa perempuan mempunyai tingkat kepatuhan pajak yang lebih tinggi daripada laki-laki, namun tidak adanya perbedaan akses pendidikan antara perempuan dan laki-laki di Indonesia menjadi alasan kenapa kepatuhan perpajakan perempuan dan laki-laki di 
Indonesia sama. Hal ini sesuai dengan pendapat Kastlunger (2010) menyatakan bahwa perbedaan hasil penelitian mengenai hubungan jenis kelamin terhadap kepatuhan perpajakan disebabkan oleh gender-role orientation, karakteristik yang terasosiasi terhadap jenis kelamin, lingkungan sosial, dan akses terhadap pendidikan pada suatu negara. Emansipasi wanita yang mendorong terbukanya akses wanita kepada pendidikan dan perubahan gender-role orientation pada suatu Negara mendorong asimilasi antara laki-laki dan perempuan yang pada akhirnya menyebabkan adanya persamaan dalam sikap dan pengambilan keputusan antara laki-laki dan perempuan.

\subsubsection{Hubungan Umur Terhadap Kepatuhan Perpajakan}

Tidak ada perbedaan yang signifikan atas kepatuhan perpajakan antara responden yang lebih muda dibandingkan responden yang lebih tua yang ditunjukkan oleh nilai $p$-value (Asymp. Sig) bernilai 0,113 lebih besar dari 0,05 sehingga dapat dinyatakan tolak $\mathrm{H}_{2}$. Hasil uji korelasi menunjukkan bahwa Umur berkorelasi signifikan $(p<0,05)$ dengan arah hubungan negatif $(r=-$ $0,137)$ terhadap kepatuhan perpajakan. Arah hubungan ini menunjukkan bahwa semakin bertambah umur seseorang, maka kepatuhan perpajakannya semakin rendah. Hasil penelitian ini sama dengan penelitian Al-Mamun et al. (2014) dimana mereka menyimpulkan bahwa umur berkorelasi negatif terhadap kepatuhan perpajakan, artinya orang yang lebih muda lebih patuh dibandingkan dengan orang yang lebih tua. Namun, hasil penelitian ini berbeda dengan Torgler dan Schaltegger (2005) dan Torgler dan Valev (2004). Hasil penelitian mereka menemukan bahwa orang yang lebih tua lebih patuh dibandingkan dengan yang lebih muda.

Perbedaan jenis pekerjaan responden mempengaruhi perbedaan nilai mean untuk masingmasing kelompok umur. Responden pada kelompok umur di bawah dan 35 tahun dan kelompok umur antara 35 tahun s.d. 45 tahun mayoritas bekerja sebagai Pegawai Negeri Sipil (PNS) dan Karyawan Swasta/BUMN dimana 85\% kelompok umur di bawah 35 tahun dan 71\% dari kelompok umur antara 35 tahun s.d 45 tahun bekerja sebagai PNS dan karyawan Swasta/BUMN. Sedangkan untuk kelompok umur antara 45 tahun s.d 55 tahun dan umur di atas 55 tahun mayoritas respoden bekerja sebagai profesional dan pengusaha dengan persentase $68 \%$ dari responden pada kelompok umur antara 45 tahun s.d 55 tahun dan $67 \%$ dari kelompok umur di atas 55 tahun. Hasil penelitian menunjukkan bahwa responden yang bekerja sebagai Pegawai Negeri Sipil (PNS) dan Karyawan Swasta/BUMN lebih patuh dari responden yang bekerja sebagai profesional dan pengusaha. Data pelaporan pihak ketiga atas penghasilan yang diterima pengusaha juga sangat minim sehingga akses Direktorat Jenderal Pajak sangat rendah atas data penghasilan pengusaha mendorong rendahnya kepatuhan perpajakan pengusaha. 
Selain penjelasan di atas, Pickhardt dan Prinz (2014) menyebutkan bahwa perbedaan hasil penelitian atas dampak faktor demografi pada kepatuhan perpajakan disebabkan oleh perbedaan norma sosial dan nilai-nilai yang ada dalam masyarakat dimana seseorang tinggal. Sikap dan perilaku seseorang akan sangat dipengaruhi oleh lingkungan sosialnya. Jika di lingkungan sosial dimana seseorang tinggal menganggap penggelapan pajak adalah aktivitas normal maka hal ini akan mendorong individu untuk menghindari pajak. Dengan kata lain, teman-teman dekat menunjukkan efek terkuat dan paling dominan pada kepatuhan perpajakan.

\subsubsection{Hubungan Tingkat Pendidikan Terhadap Kepatuhan Perpajakan}

Ada perbedaan signifikan kepatuhan perpajakan antara responden yang tingkat pendidikannya berbeda yang ditunjukkan oleh p-value (Asymp. Sig) bernilai 0,021 lebih kecil dari 0,05 sehingga dapat dinyatakan terima $\mathrm{H}_{3}$. Uji korelasi Spearman menunjukkan bahwa variabel tingkat pendidikan berkorelasi negatif $(r=-0,168)$ secara signifikan $(p=0,003<0,05)$ dengan kepatuhan perpajakan. Arah hubungan ini menunjukkan bahwa semakin tinggi tingkat pendidikan seseorang, kepatuhan perpajakannya malah menurun.

Meskipun hasil penelitian ini sejalan dengan Lewis (1982) yang menyatakan bahwa orang yang mempunyai pendidikan yang lebih tinggi akan lebih mengetahui peraturan pajak dan kebijakan fiskal serta mengetahui tentang cara-cara menghindari pajak (tax avoidance) dan penyelundupan pajak (tax evasion) sehingga tidak dapat dikatakan bahwa orang yang berpendidikan tinggi lebih patuh dari yang berpendidikan rendah, namun hasil penelitian ini berbeda dengan hasil penelitian Torgler dan Schaltegger (2005) dan Al-Mamun et al. (2014) yang menemukan bahwa pendidikan berkorelasi positif dengan kepatuhan perpajakan. Dengan kata lain, semakin tinggi pendidikan seseorang, maka dia semakin patuh. Jika dilihat lebih lanjut statistik deskriptif responden, jenis pekerjaan untuk setiap tingkat pendidikan responden menyebar secara merata sehingga pengaruh variabel jenis pekerjaan pada hasil uji pengaruh variabel tingkat pendidikan dan kepatuhan perpajakan bisa dikatakan tidak signifikan. Namun, variabel tingkat penghasilan responden bisa memengaruhi hubungan antara variabel tingkat pendidikan dengan variabel kepatuhan perpajakan karena Uji Kruskal-Waliss dan Uji Korelasi Sprearmann kedua variabel ini menunjukkan hasil yang sama, yakni semakin tinggi penghasilan seseorang, maka kepatuhan perpajakannya malah menurun. Berdasarkan statistik deskriptif, responden dengan tingkat pendidikan SMA dan DIII memiliki tingkat penghasilannya berkisar pada Rp 0 s.d Rp 250 juta/tahun. Sedangkan tingkat penghasilan 98\% responden dengan tingkat pendidikan S2 dan S3 berada di atasRp 250 juta/tahun. 


\subsubsection{Hubungan Status Pernikahan Terhadap Kepatuhan Perpajakan}

Tidak ada perbedaan kepatuhan perpajakan antara responden yang belum menikah dengan responden yang sudah menikah yang ditunjukan oleh $p$-value (Asymp. Sig) bernilai 0,390 yang berarti lebih besar dari 0,05 sehingga dapat dinyatakan tolak $\mathrm{H}_{4}$. Uji korelasi menunjukkan bahwa status perkawinan dan kepatuhan perpajakan berkorelasi tidak signifikan $(p=0,391>0,05)$ dengan arah negatif $(r=-0,049)$. Dari kedua hasil uji ini dapat disimpulkan bahwa status perkawinan tidak memengaruhi kepatuhan perpajakan.

Hasil penelitian ini sama dengan Andreoni et al. (1998) yang menemukan bahwa tingkat kepatuhan pasangan yang belum menikah lebih tinggi dari pada individu yang sudah menikah. Namun, hasil penelitian ini berbeda dengan Torgler (2003) yang menemukan bahwa individu yang lajang memiliki kepatuhan perpajakan lebih rendah dibandingkan dengan pasangan yang sudah menikah. Penjelasan atas perbedaan hasil penelitian ini adalah pendapat Pickhardt dan Prinz (2014) menyebutkan bahwa perbedaan hasil penelitian antara faktor demografi dengan kepatuhan perpajakan disebabkan oleh perbedaan norma sosial dan nilai-nilai yang ada dalam masyarakat dimana seseorang tinggal. Sikap dan perilaku seseorang akan sangat dipengaruhi oleh lingkungan sosialnya. Jika di lingkungan sosial dimana seseorang tinggal menganggap penggelapan pajak adalah aktivitas normal maka hal ini akan mendorong individu untuk menghindari pajak.

\subsubsection{Hubungan Jenis Pekerjaan Terhadap Kepatuhan Perpajakan}

Ada perbedaan kepatuhan perpajakan antar responden yang memiliki jenis pekerjaan yang berbeda yang ditunjukkan oleh $p$-value (Asymp. Sig) bernilai 0,000 lebih kecil dari 0,05 sehingga dapat dinyatakan terima $\mathrm{H}_{5}$. Selaras dengan uji Kruskal-Wallis, uji korelasi Spearman mengonfirmasi bahwa jenis pekerjaan berpengaruh sangat signifikan ( $p$-value $=0,000<0,05$ ) terhadap kepatuhan perpajakan dengan arah korelasi negatif $(r=-0,220)$. Hasil uji korelasi ini menunjukkan bahwa responden yang bekerja sebagai Pegawai Negeri Sipil lebih patuh dibandingkan dengan responden yang memiliki usaha sendiri (pengusaha).

Dari kedua pengujian ini, disimpulkan bahwa jenis pekerjaan seseorang berhubungan dengan kepatuhan perpajakannya. Responden yang bekerja sebagai Pegawai/Karyawan lebih patuh karena pajak penghasilan secara rutin dipotong oleh pemberi kerja atas penghasilan yang dibayarkan. Selain itu, pemberi kerja umumnya mensyaratkan NPWP dalam pelamaran kerja. Bahkan, beberapa pemberi kerja terutama instansi pemerintah mewajibkan pegawainya untuk menyampaikan SPT Tahunan tepat waktu dan memasukkan ketepatan waktu penyampaian SPT Tahunan ini sebagai komponen penilaian kinerja. Hal inilah yang menjadi 
penyebab orang yang bekerja sebagai Pegawai Negeri Sipil dan Karyawan lebih patuh. Sedangkan, responden yang memiliki usaha sendiri, pembayaran pajaknya dilakukan sendiri sehingga biaya kepatuhannya lebih tinggi dan memiliki lebih banyak kesempatan untuk melakukan tax evasion. Hasil penelitian ini mengkonfirmasi penelitian Lewis (1982) yang menyimpulkan bahwa pengusaha memiliki biaya kepatuhan pajak yang tinggi sehingga mereka cenderung menggelapkan pajak.

\subsubsection{Hubungan Tingkat Penghasilan Terhadap Kepatuhan Perpajakan}

Ada perbedaan kepatuhan perpajakan antara responden yang memiliki tingkat penghasilan berbeda yang ditunjukkan oleh $p$-value (Asymp. Sig) bernilai 0,008 lebih kecil dari 0,05 sehingga dapat dinyatakan terima $\mathrm{H}_{6}$. Uji korelasi menunjukkan bahwa tingkat penghasilan berkorelasi sangat signifikan ( $p$-value $=0,001<0,05)$ dengan arah korelasi negatif $(r=-0,192)$ dengan kepatuhan perpajakan. Hal ini menunjukkan bahwa semakin tinggi penghasilan responden, kepatuhan perpajakannya malah menurun. Dari kedua pengujian ini, dapat disimpulkan bahwa tingkat penghasilan berdampak pada kepatuhan perpajakan dimana semakin tinggi penghasilan seseorang, semakin rendah kepatuhan perpajakannya.

Hasil penelitian ini sejalan Trivedi dan Chung (2006) dimana mereka melaporkan bahwa terdapat hubungan negatif antara pendapatan dan kepatuhan perpajakan. Tarif pajak progresif yang diterapkan di Indonesia menjadi alasan arah korelasi negatif antara variabel tingkat penghasilan dan variabel kepatuhan perpajakan seperti yang diutarakan oleh Torgler dan Schneider (2004) pada penelitiannya bahwa tarif pajak progresif mendorong individu berpenghasilan tinggi untuk melakukan penggelapan pajak. Arah korelasi negatif antara variabel tingkat penghasilan dan variabel kepatuhan perpajakan, dimana semakin tinggi penghasilan seseorang maka kepatuhan perpajakannya semakin rendah, didukung oleh data deskriptif responden bahwa 55\% yang penghasilan di atas $\mathrm{Rp} 500$ juta/tahun adalah wiraswasta. Seperti yang dijelaskan sebelumnya, Wajib Pajak wiraswasta memiliki biaya kepatuhan yang lebih tinggi sehingga kepatuhan perpajakannya lebih rendah dari Wajib Pajak yang bekerja sebagai Pegawai Negeri Sipil dan Karyawan Swasta. Selain itu, data pelaporan pihak ketiga atas penghasilan yang diterima wiraswata sangat minim sehingga akses Direktorat Jenderal Pajak sangat rendah atas data penghasilan wiraswasta. Hal ini mendorong rendahnya kepatuhan perpajakan wiraswasta. 


\section{Kesimpulan, Keterbatasan, dan Saran}

Penelitian ini bertujuan untuk menguji pengaruh dari faktor demografi terhadap kepatuhan perpajakan. Jumlah sampel yang digunakan dalam penelitian ini adalah 304 responden yang melakukan pengisian kuesioner secara online. Berdasarkan hasil analisis yang telah dilakukan, maka dapat disimpulkan bahwa:

a. Tidak ada perbedaan kepatuhan perpajakan antara responden berjenis kelamin laki-laki maupun responden berjenis kelamin perempuan. Hal ini terjadi karena di Indonesia laki-laki dan perempuan memiliki akses yang sama terhadap pendidikan yang menyebabkan adanya asimilasi yang mendorong persamaan persepsi antara laki-laki dan perempuan atas kewajiban perpajakan dan manfaat dari pajak.

b. Umur tidak berdampak kepada kepatuhan perpajakan, meskipun ditemukan bahwa umur berkorelasi negatif dengan kepatuhan perpajakan. Arah hubungan ini menunjukkan orang yang lebih tua memiliki kepatuhan perpajakan yang lebih rendah dari orang yang lebih muda.

c. Tingkat pendidikan berhubungan signifikan kepada kepatuhan perpajakan. Selain itu ditemukan bahwa tingkat pendidikan berkorelasi negatif secara signifikan dengan kepatuhan perpajakan, dimana semakin tinggi tingkat pendidikan seseorang, kepatuhan perpajakannya malah menurun. Hal ini bisa disebabkan karena yang mempunyai pendidikan yang lebih tinggi akan lebih mengetahui peraturan pajak dan kebijakan fiskal serta mengetahui tentang cara-cara menghindari pajak (tax avoidance) dan penyelundupan pajak (tax evasion).

d. Tidak ada perbedaan kepatuhan perpajakan antara responden yang belum menikah dengan responden yang sudah menikah. Hasil uji korelasi juga menunjukkan bahwa tidak ada hubungan yang signifikan antara status perkawinan dan kepatuhan perpajakan.

e. Jenis pekerjaan seseorang berdampak pada kepatuhan perpajakannya, dimana orang yang bekerja sebagai Pegawai Negeri Sipil lebih patuh dibandingkan dengan Wiraswasta. Hal ini bisa dipahami karena atas penghasilan yang diterima Pegawai/Karyawan secara rutin dipotong oleh pemberi kerja, sedangkan wiraswasta memiliki lebih banyak kesempatan untuk melakukan tax evasion. Selain itu, pemberi kerja umumnya mensyaratkan kepemilikan NPWP sebagai syarat dalam pelamaran kerja. Bahkan, beberapa pemberi kerja terutama instansi pemerintah mewajibkan pegawainya untuk menyampaikan SPT Tahunan tepat waktu.

f. Tingkat penghasilan berdampak pada kepatuhan perpajakan dimana semakin tinggi penghasilan seseorang, semakin rendah kepatuhan perpajakannya. Menurut Torgler dan Scheider (2004), tarif pajak progresif mendorong individu berpenghasilan besar untuk melakukan penggelapan pajak. 
Penulis tidak memiliki akses terhadap data sekunder berupa data pemenuhan kewajiban perpajakan responden sehingga penulis tidak bisa melakukan cross-check atas kepatuhan perpajakan sehingga analisis yang dilakukan hanya berdasarkan pada pengisian kuesioner yang dilakukan oleh responden. Diharapkan pada penelitian berikutnya, peneliti dapat menjalin kerja sama dengan pihak otoritas perpajakan untuk mendapatkan akses terhadap pemenuhan perpajakan responden sehingga peneliti bisa melakukan konfirmasi atas pengisian kuesioner yang dilakukan oleh responden. Selain menyebarkan secara online, penyebaran kuesioner diharapkan juga menjangkau semua lapisan masyarakat terutama masyarakat yang bergerak di informal economy.

\section{Daftar Pustaka}

Alm, James, Jackson, Betty, dan Michael J. M. 1992. Estimating the Determinants of Taxpayer Compliance with Experimental Data, National Tax Journal, 45:1, pp. 107-14.

Alm, James dan Benno Torgler. 2011. Do Ethics Matter? Tax Compliance and Morality. Journal of Business Ethics Volume 101, Issue 4, pp 635-651.

Al-Mamun, Abdullah, Harry Entebang, Shazali Abu Mansor, Qaiser Rafique Yasser, dan Thurai Murugan Nathan. (2014). The Impact of Demografic Factors on Tax Compliance Attitude and Behavior in Malaysia. Journal of Finance, Accounting and Management, 5(1), pp. 109-124

Andreoni, J., B. Erard, dan J. Feinstein. 1998. Tax Compliance. Journal of Economic Literature 36 No. 2: $818-860$.

Chung, Janne dan Viswanath Umashanker Trivedi. 2006. The Effect of Friendly Persuasion and Gender on Tax Compliance Behavior. Journal of Business Ethics, Volume 47, Issue 2, pp 133-145.

Jackson, B. R., dan V. C. Milliron. 1986. Tax Compliance Research: Findings, Problems, and Prospects, J. Account. Lit. 5: 125-165.

James, Simon dan Clinton Alley. 2002. Tax compliance, self-assessment and tax administration. Journal of Finance and Management in Public Services, Vol. 2, No. 2: pp. 27-42.

Kastlunger, Barbara. 2010. Sex differences in tax compliance: Differentiating between demographic sex, gender-role orientation, and prenatal masculinization (2D:4D). Journal of Economic Psychology Vol. 31: pp. 542-552.

Lewis, A. 1982. The Psychology of Taxation. Oxford: Blackwell.

McGee, R. W., dan Smith, S. R. 2007. Ethics, Tax Evasion, Gender and Age: An Empirical Study of Utah Opinion. Andreas School of Business Working Paper Series, Barry University, Miami Shores.

Nurmantu, Safri. 2005. Pengantar Perpajakan. Jakarta: PT Granit. 
Pickhardt, M., dan Prinz, A. 2014. Behavioral dynamics of tax evasion - A survey. Journal of Economic Psychology, 40, 1-19.

Plumley, A. 2005. Preliminary Update of the Tax Year 2001 Individual Income Tax Underreporting Gap Estimates. Paper Presented at the 2005 Internal Revenue Service Research Conference. Washington DC: IRS.

Roxas, M. L., dan Stoneback, J. Y. 2004. The Importance of Gender Across Cultures in Ethical Decision- Making. Journal of Business Ethics Vol. 50: pp. 149 - 165.

Song, Y. D., dan T. E. Yarbrough. 1978. Tax Ethics and Taxpayer Attitude: A Survey Public Administration Review September-October: 442-452.

Torgler, Benno. 2003. Tax Morale and Tax Compliance: A Cross-Culture Comparison. National Tax Assoc, Annual Conference.

Torgler, B., dan N.T. Valev. 2004. Corruption and Age. CREMA Working Paper, No. 2004-24, Basel.

Torgler, B., dan F. Schneider. 2004. Attitudes Towards Paying Taxes in Austria: An Empirical Analysis. CREMA Working Paper, No. 2004-27, Basel.

Torgler, B., dan Schaltegger, C. A. 2005. Tax Morale and Fiscal Policy. Working Paper (CREMA (Center for Research in Economics, Management and the Arts) and Swiss Federal Tax Administration, University of St. Gallen).

Tittle, C. 1980. Sanctions and Social Deviance: The Question of Deterrence. Praeger, New York. 